\title{
Ageing, testicular tumours and the pituitary-testis axis in dogs
}

\author{
M A J Peters, F H de Jong ${ }^{4}$, K J Teerds ${ }^{1}$, D G de Rooij ${ }^{3}$, \\ S J Dieleman ${ }^{2}$ and $\mathbf{F} \mathbf{J}$ van Sluijs
} Department of Clinical Sciences of Companion Animals, Faculty of Veterinary Medicine, Universiteit Utrecht, The Netherlands
${ }^{1}$ Department of Biochemistry and Cell Biology, Faculty of Veterinary Medicine, Universiteit Utrecht, The Netherlands
${ }^{2}$ Department of Farm Animal Health, Faculty of Veterinary Medicine, Universiteit Utrecht, The Netherlands
${ }^{3}$ Department of Cell Biology, University Medical Center Utrecht, Universiteit Utrecht, The Netherlands
${ }^{4}$ Department of Endocrinology and Reproduction, Erasmus University Rotterdam, The Netherlands
(Correspondence should be addressed to M A J Peters who is now at Diedenweg 145, 6706 CN Wageningen; Email: majpeters@wish.net)
(Requests for offprints should be addressed to F J van Sluijs, Department of Clinical Sciences of Companion Animals, Faculty of Veterinary Medicine,
P O Box 80154, 3508 TD Utrecht, The Netherlands; Email: f.j.vanSluijs@vet.uu.nl)

\begin{abstract}
Dogs of different ages without testicular diseases were evaluated to study possible age-related changes in hormone concentrations in serum. Dogs with testicular tumours were also investigated to study the relation between tumour type and hormone concentrations; in this study, dogs with Sertoli cell tumours, Leydig cell tumours and seminomas were included. We measured testosterone, oestradiol, LH, FSH and inhibin-like immunoreactivity concentrations in peripheral venous and testicular venous blood of these animals.

In normal dogs there appeared to be no age-related changes in the concentrations of the investigated hormones, except for a significant age-related decrease in oestradiol concentrations in testicular venous blood $(P<0 \cdot 02)$. Dogs with a Sertoli cell tumour had greater oestradiol concentrations and inhibin-like immunoreactivity in both peripheral and testicular venous blood than did dogs without a neoplasm $(P<0 \cdot 05)$. Testosterone concentrations were reduced in dogs with Sertoli cell tumours, as were FSH and LH. Feminisation occurred in eight of 13 dogs with a Sertoli cell tumour and in two of 14 dogs with a Leydig cell tumour; it was accompanied by a significantly greater oestradiol concentration than in normal dogs and in
\end{abstract}

dogs with Sertoli cell tumours without signs of feminisation. Dogs with a Leydig cell tumour had greater concentrations of oestradiol and inhibin-like immunoreactivity in both peripheral venous and testicular venous blood than did dogs without a neoplasm $(P<0 \cdot 05)$. The testosterone concentration in testicular venous blood of these dogs was lower than that in dogs with normal testes. The concentration of LH in peripheral venous blood was also reduced $(P<0 \cdot 05)$. Hormone concentrations in dogs with a seminoma were not different from those in normal dogs.

It was concluded that seminomas are not endocrinologically active. In contrast, both Sertoli cell tumours and Leydig cell tumours can cause increased oestrogen production leading to signs of feminisation. These tumours also have considerable amounts of inhibin-like immunoreactivity, but only in Sertoli cell tumours does this result in a reduction in FSH concentrations, suggesting that Sertoli cell tumours secrete dimeric inhibin, whereas Leydig cell tumours presumably produce loose $\alpha$-subunits that cross-react in the inhibin assay but are not biologically active.

Journal of Endocrinology (2000) 166, 153-161

\section{Introduction}

A decline in reproductive function is a well-known feature of ageing in mammalian species (Meites 1986). Many studies have revealed an age-dependent decrease in free testosterone concentrations in the human male, in combination with unchanged or increased oestradiol concentrations and increased concentrations of luteinizing hormone ( $\mathrm{LH}$ ) and follicle-stimulating hormone (FSH) (Neaves et al. 1984, Finch \& Schneider 1985, Kaiser \& Morley 1994). In ageing male rats, a decrease in testoster- one concentration has been reported (Karpas et al. 1983, Wang et al. 1993, Zirkin et al. 1993, Chen et al. 1994), in addition to a reduction in plasma gonadotrophin concentrations, which is in contrast to the findings in men (Zirkin et al. 1993).

In male dogs, conflicting results have been obtained in studies on the effect of ageing on plasma testosterone concentrations. Either no reduction with age (Taha \& Noakes 1982, Lowseth et al. 1990) or decreasing testosterone concentrations has been reported (Bondarenko et al. 1979, Günzel Apel et al. 1990); in accordance with the 
Table 1 Weight and corresponding age at which dogs are considered to be geriatric (modified from Goldston et al. (1989)), numbers of dogs with normal testes and with testis tumours per weight category and their age range, and type of tumour and the numbers of dogs with such tumours

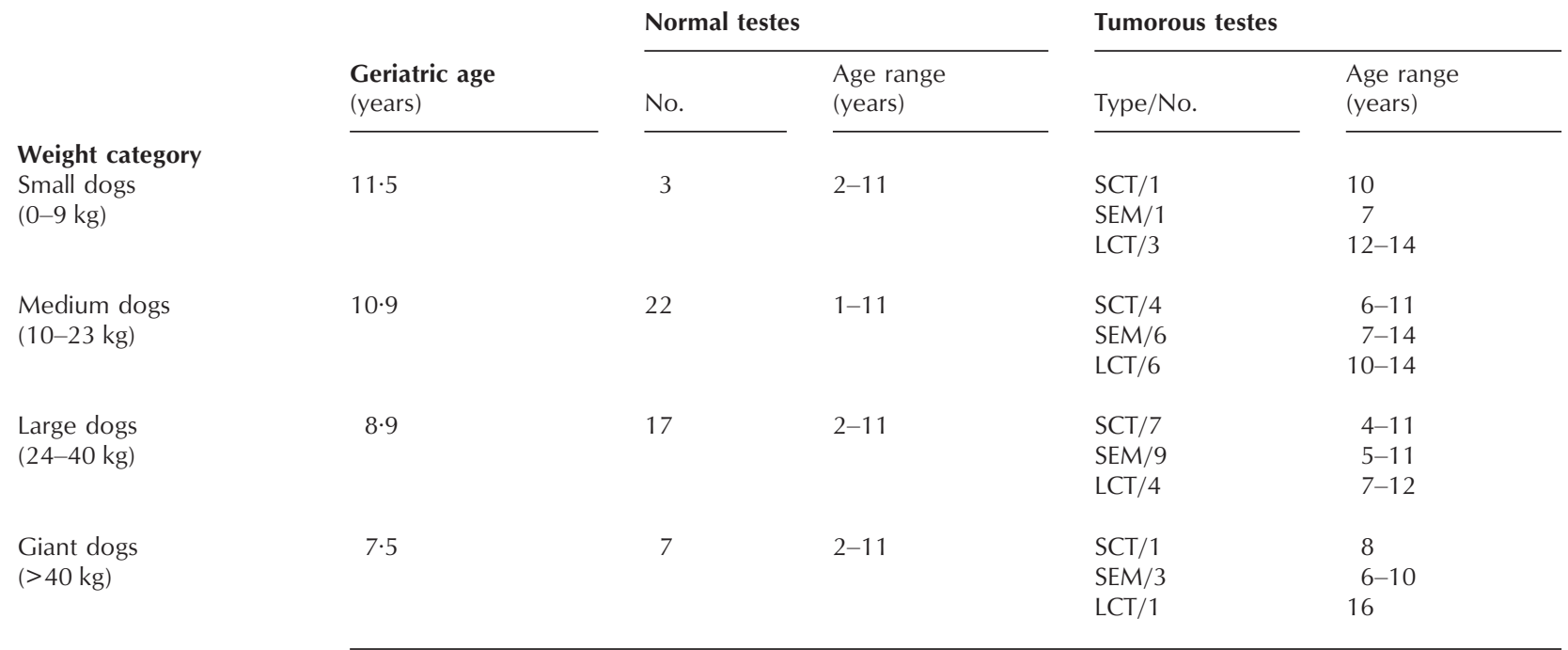

Normal, dogs with normal testes; SCT, Sertoli cell tumour; SEM, seminoma; LCT, Leydig cell tumour.

latter observation, lower LH concentrations were observed in aged dogs also (Günzel Apel et al. 1990).

Testicular neoplasia and Leydig cell hyperplasia are common findings in aged dogs. The prevalence of testicular tumours can be as high as 60\% in old dogs (Mosier 1989). In men, however, testicular tumours occur most often in adults younger than 40 years of age (Looijenga et al. 1994). The three main types of testicular tumours in dogs are Sertoli cell tumours, seminomas and Leydig cell tumours; mixed tumours are often observed (Nielsen \& Kennedy 1990). Cryptorchidism is an important risk factor for the development of testicular tumours, causing a 26-fold increase in the risk for Sertoli cell tumours and a 15-fold increase for seminomas (Hayes et al. 1985). Although Sertoli cell tumours and seminomas are considered to be potentially malignant, they seldom metastasise in the dog, whereas seminomas in men are highly malignant (Swerdlow 1993).

In dogs, testicular tumours may be associated with clinical signs such as feminisation and alopecia, especially when a Sertoli cell tumour is involved (Theilen \& Madewell 1987). This syndrome is characterised by bilateral symmetrical alopecia, gynaecomastia, atrophy of the contralateral testis, a pendulous prepuce, attractiveness to other male dogs and, in severe cases, bone marrow depression. The last of these may be irreversible and is a potentially lethal complication (Rijnberk 1996). Feminisation occurs in $19 \%$ of dogs with a histologically diagnosed Sertoli cell tumour and in 5\% of dogs with a Leydig cell tumour (Peters \& van Sluijs 1996). Feminisation is attributed to the secretion of excessive amounts of oestrogens by the tumour. Sertoli cell tumours are known to produce oestrogens (Rijnberk 1996), but it is not clear whether Leydig cell tumours and seminomas also secrete oestrogens. In humans, oestradiol in blood is derived mainly from Leydig cells and adipocytes after conversion from testosterone, but Sertoli cells and germ cells can also produce oestrogen (Sharpe 1998).

To investigate possible effects of reproductive ageing and testicular tumours on pituitary-testicular function in dogs, we have measured testosterone, oestradiol, LH, FSH and inhibin-like immunoreactivity in peripheral venous and testicular venous blood. Dogs of different ages without testicular diseases and dogs with Sertoli cell tumours, seminomas and Leydig cell tumours were studied.

\section{Materials and Methods}

\section{Animals}

Peripheral venous and testicular venous blood was collected from 95 dogs of different breeds and ages before castration. This operation was performed for a variety of reasons not related to testicular diseases $(n=49$ : benign prostatic hyperplasia (BPH), balanoposthitis, perineal hernia or unwanted behaviour), or because of a testicular tumour $(n=46$; tumour types are shown in Table 1$)$. In some cases it was not possible to collect blood from both the peripheral and the testicular vein. Cryptorchid dogs without testis tumours were excluded from this study. Nine of the 46 dogs with testicular tumours were cryptorchid. 
In order to compare data from dogs of different breeds, we applied a correction factor based on the fact that dogs of small breeds live longer than those of large breeds. We expressed the age of a dog at the time of castration as the percentage of its geriatric age, using the method of Goldston et al. (1989). This method groups dogs into categories according to body weight and the age at which they become geriatric (Table 1). Hence, we considered dogs to be old (geriatric) when their age was equal to or greater than $100 \%$ of the geriatric age according to their category of body weight.

\section{Blood sampling}

Five millilitres of blood were collected from an external jugular vein immediately after the induction of anaesthesia, and placed in an EDTA-coated tube. This blood was referred to as peripheral venous blood. During orchidectomy, the ductus deferens and the pampiniform plexus were double clamped and transected between the clamps. The clamp on the testicular side of the plexus was removed immediately after transection and the blood draining from both spermatic veins was also collected in an EDTAcoated tube and referred to as testicular venous blood. The tubes were centrifuged and the plasma obtained was stored at $-20{ }^{\circ} \mathrm{C}$ until required for analysis. In some cases not enough blood could be collected to perform all hormone measurements. As a result of this the number of samples is different for each analysis.

\section{Hormone measurements}

The concentration of oestradiol in plasma was measured by RIA using kits supplied by Diagnostic Products Corporation (Los Angeles, CA, USA). Testosterone concentration in plasma was assayed by RIA as described by Verjans et al. (1973). The intra- and interassay coefficients of variation were respectively $<5 \%$ and $<8 \%$ for oestradiol and $<6 \%$ and $<9 \%$ for testosterone; the assay sensitivities were 0.01 and $0.2 \mathrm{nmol} / 1$, respectively. Plasma inhibinlike immunoactivity was measured using an antiserum against purified $32 \mathrm{kDa}$ bovine follicular fluid (bFF) inhibin (No. 1989) and using iodinated $32 \mathrm{kDa}$ bFF inhibin as the tracer (purchased from the Department of Anatomy, Monash University, Melbourne, Victoria, Australia) (Robertson et al. 1989). Validation was performed earlier (Grootenhuis et al. 1990). The sensitivity of the immunoassay was $0.65 \mathrm{U}$ and the intra- and interassay coefficients of variation were $<7 \cdot 5 \%$ and $<12 \%$ respectively. Plasma FSH was determined using a rat FSH RIA as described by Grootenhuis et al. (1990). The results were expressed in terms of NIDDK-rat FSH-RP-1 standard. Serial dilutions of plasma from castrated dogs resulted in curves parallel to the rat FSH standard after logit-log transformation. Intra- and interassay coefficients of variation were $5 \cdot 1 \%$ and $11 \cdot 5 \%$, respectively, and the sensitivity of the assay was $0 \cdot 2 \mathrm{ng} / \mathrm{ml}$. Plasma LH concentration was measured by a heterologous RIA as described by Knol et al. (1993). A sheep antibody, CSU-204 (a gift from Dr Niswender, Colorado State University, Fort Collins, CO, USA), radioiodinated NIAMDD-bLH-4 and canine pituitary standard LER 1685-1 were used in this assay. The sensitivity of the LH assay was $1 \mathrm{ng} / \mathrm{ml}$.

\section{Characterisation of tumours}

Tumours were classified microscopically according to the morphological criteria of Nielsen \& Kennedy (1990), together with immunohistochemical staining using Leydig cell-specific antibodies against the LH-receptor and $3 \beta-$ hydroxy steroid dehydrogenase ( $3 \beta-H S D)$ (M A J Peters, K J Teerds, J van der Gaag, D G de Rooij \& F J van Sluijs, unpublished observations) that have been shown to be Leydig-cell-specific in other species (Bukovsky et al. 1993, Faustin et al. 1995, Teerds et al. 1999).

Sertoli cell tumours, Leydig cell tumours and seminomas were recorded separately. Mixed tumours were excluded from this study. Tubules overgrown with Sertoli cells or germ cells were classified as intratubular Sertoli cell tumour or intratubular seminoma. Testes containing these very small tumours, which were only microscopically detectable in very few seminiferous tubules, were categorised as normal because alterations in the investigated hormones were not expected in these dogs. A neoplasm was considered to be a solid tumour when a discrete nodule or group of Sertoli cells or seminoma cells was visible outside the seminiferous tubules.

\section{Hormone concentrations}

The hormone concentrations in blood collected from the two spermatic veins of dogs with two normal testes or two testes with the same type of tumour were averaged. Hormone concentrations of the unaffected and the affected testis in dogs with a unilateral tumour were recorded separately. Concentrations of hormones in testicular venous blood from testes with tumours were compared with concentrations in testicular venous blood from the contralateral unaffected testis and with the mean concentrations in testicular venous blood of dogs with two normal testes.

Peripheral venous hormone concentrations in dogs with tumours were compared with those in normal dogs.

\section{Statistics}

The effect of age on hormone concentrations was investigated in the 49 dogs without testicular diseases. Correlations between hormone concentrations were examined in dogs both without and with testis tumours.

For all dogs the results of the hormone measurements were log-transformed before a general linear model was applied to compare the main effects between different types of tumours. The hormone concentration was the 


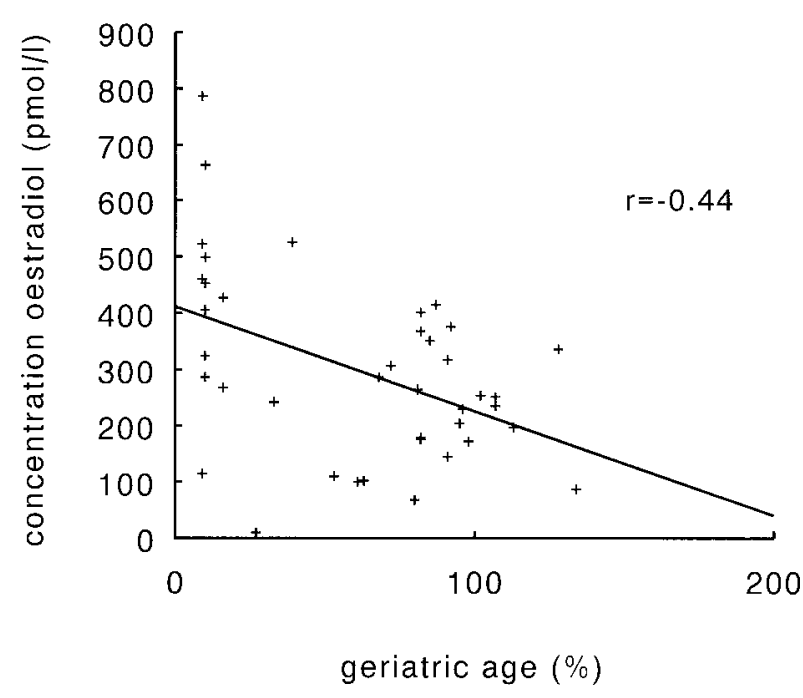

Figure 1 Relationship between ageing and oestradiol concentration in testicular venous blood of 40 dogs without testicular disease. All dogs showed normal spermatogenesis in cross-sections of the seminiferous tubules. Age is represented as percentage of geriatric age, as explained in Materials and Methods. $r$, coefficient of correlation.

variable, and weight and relative age of the dog were the covariant factors in this analysis of variance. SPSS $7 \cdot 5$ software was used for statistical analyses and $P<0 \cdot 05$ was considered significant.

\section{Results}

Dogs with two normal testes

In dogs without testicular tumours $(n=49)$ there was no significant relation between the geriatric age of the dog and the concentrations of gonadotrophins, testosterone and inhibin-like immunoreactivity in peripheral venous blood or testicular venous blood. Only the oestradiol concentration in testicular venous, but not peripheral venous, blood appeared to decrease with geriatric age $(r=-0 \cdot 44$, $P=0 \cdot 02, n=40$; Fig. 1).

The coefficient of correlation between $\mathrm{LH}$ and FSH in peripheral venous blood of normal dogs was $0 \cdot 37$ $(P=0 \cdot 016, n=41$; Fig. 2$)$. Other significant correlations were found between FSH and testosterone $(r=0 \cdot 31$, $P<0 \cdot 05, n=43), \mathrm{FSH}$ and oestradiol $(r=0 \cdot 36, P<0 \cdot 02$, $n=43$; Fig. 3), and between oestradiol and testosterone in peripheral venous blood $(r=0 \cdot 42, P=0 \cdot 005, n=43)$ and in testicular venous blood $(r=0 \cdot 37, P=0 \cdot 02, n=39$; Fig. 4). Concentrations of other hormones were not significantly related.

\section{Dogs with a Sertoli cell tumour}

Dogs with a Sertoli cell tumour $(n=13)$ had significantly greater concentrations of oestradiol and inhibin-like

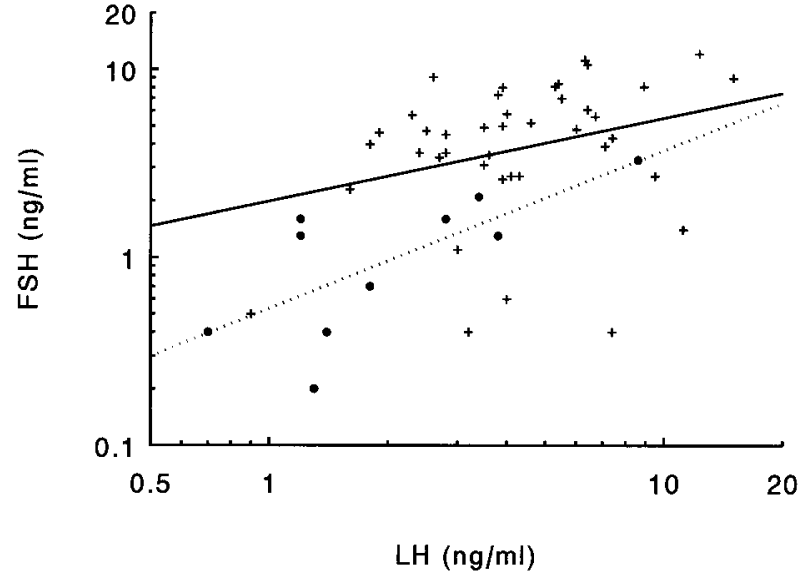

Figure 2 Relationship between $\mathrm{LH}$ and FSH in peripheral venous blood of dogs without testicular disease (+, solid line) and dogs with a Sertoli cell tumour $(\bullet$, dotted line).

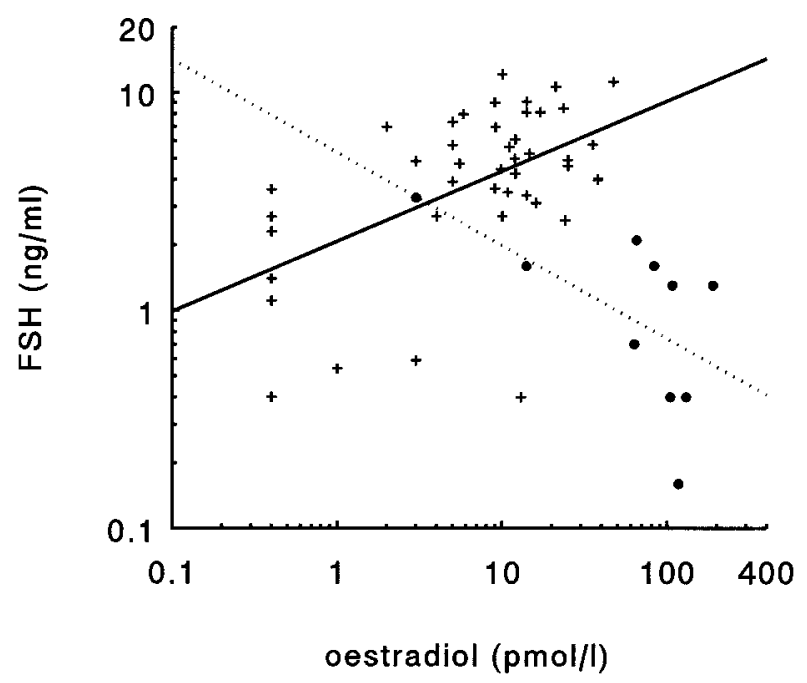

Figure 3 Relationship between FSH and oestradiol in peripheral venous blood of dogs without testicular disease $(+$, solid line) and dogs with a Sertoli cell tumour $(\bullet$, dotted line).

immunoreactivity than did normal dogs, both in peripheral venous blood $(P=0 \cdot 001$; number of samples $(n)=10$ compared with $n=44$, and $n=9$ compared with $n=43$, respectively) and in testicular venous blood $(P<0 \cdot 05 ; n=4$ compared with $n=40$, and $n=4$ compared with $n=41$, respectively) (Table 2 ). Testosterone concentrations in dogs with Sertoli cell tumours were decreased both in peripheral venous blood and in testicular venous blood $(P<0 \cdot 001 ; n=9$ compared with $n=43$, and $n=4$ compared with $n=40$, respectively; Table 2). FSH and LH concentrations in peripheral venous blood were less in dogs with Sertoli cell tumours than in dogs with normal testes $(P=0 \cdot 001, n=10$ compared with $n=43 ; P=0 \cdot 005, n=13$ compared with $n=43$, respectively; Table 2 ). 


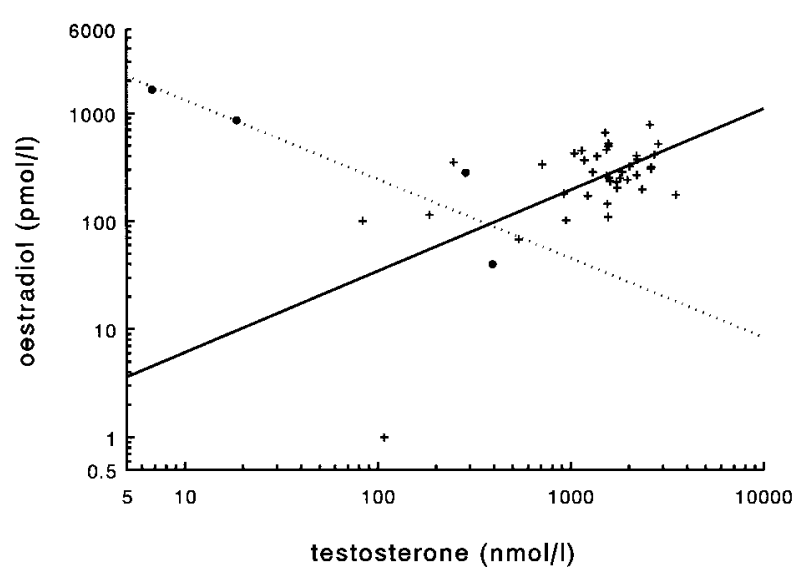

Figure 4 Relationship between oestradiol and testosterone in testicular venous blood of dogs without testicular disease $(+$, solid line) and dogs with a Sertoli cell tumour $(\boldsymbol{O}$, dotted line).

Feminisation occurred in eight dogs with a Sertoli cell tumour. The oestradiol concentrations in peripheral venous blood $(114 \pm 15 \mathrm{pmol} / \mathrm{l} ; n=7)$ and testicular venous blood (1258 $\pm 399 \mathrm{pmol} / \mathrm{l} ; n=2)$ from these dogs were significantly greater than those in dogs with nonfeminising Sertoli cell tumours ( $27 \pm 19 \mathrm{pmol} / 1, n=3$, and $161 \pm 121 \mathrm{pmol} / 1, n=2$, respectively; $P<0 \cdot 001)$.

The coefficient of correlation between $\mathrm{LH}$ and $\mathrm{FSH}$ in peripheral venous blood was $0.90(P<0 \cdot 001, n=10$; Fig. 2 , Table 3); between $\mathrm{LH}$ and oestradiol it was -0.64 $(P<0 \cdot 05, n=10$; Table 3$)$, and between FSH and oestradiol it was $-0.57(P<0 \cdot 05, n=10$; Fig. 3, Table 3). The coefficient of correlation between testosterone and oestradiol was $-0.90(P=0.05, n=4$; Fig. 4, Table 3$)$ and between testosterone and inhibin it was $-0.93(P<0 \cdot 05$, $n=4$; Table 3). Other correlations between hormone concentrations were not significant.

\section{Dogs with a Leydig cell tumour}

Fourteen dogs had a Leydig cell tumour and testicular venous blood was collected from eight of them. Moderate feminisation was reported in two of these dogs, in both of which there was atrophy of the contralateral testis and extensive alopecia. One dog had anaemia and the other dog had slight gynaecomastia. The oestradiol concentrations in these dogs were increased.

Testicles containing a Leydig cell tumour unilaterally secreted more oestradiol and more inhibin-like immunoreactivity but less testosterone than did normal testes $(P<0 \cdot 05)$. These differences were also reflected in peripheral venous blood (Table 2).

The oestradiol concentration was significantly lower in testicular venous blood from dogs with bilateral Leydig cell tumours $(n=2)$ than in testicular venous blood from the unilaterally affected testes $(n=5)$, whereas testosterone concentrations were not significantly different. Inhibinlike immunoreactivity was greatest in testicular venous blood when there were bilateral Leydig cell tumours.

The levels of inhibin-like immunoreactivity and oestradiol concentrations in blood from the contralateral unaffected testis were comparable to those in blood from normal healthy testes, but testosterone concentrations

Table 2 Mean \pm S.E. hormone concentrations (number of samples) in testicular and peripheral venous blood from dogs with normal testes and dogs with testicular tumours. Hormone concentrations were measured in testicular venous blood from the testis containing a tumour and from the contralateral unaffected testis. These values were compared with each other and with those in testiuclar venous blood from dogs with normal testes. Only in the case of Leydig cell tumours were there two dogs with bilaterally affected testes, making comparisons between uni- and bilaterally affected testes possible. For peripheral venous blood, hormone concentrations in dogs with a testis tumour were compared with those in dogs with normal testes. $\mathrm{LH}$ and FSH were measured only in peripheral venous blood

Testicular venous blood
Normal
SCT
Contralateral
SEM
Contralateral
LCT
Contralateral
Bilateral LCT

Peripheral venous blood

Normal
SCT
SEM
LCT

Inhibin

$(\mathrm{U} / \mathrm{ml})$

\section{Oestradiol \\ $(\mathrm{pmol} / \mathrm{l})$}

$\begin{aligned} 261 & \pm 32^{\mathrm{ab}}(41) \dagger \\ 1082 & \pm 519^{\mathrm{a}}(4) \\ 104 & \pm 72(2) \\ 417 & \pm 175(9) \\ 222 & \pm 106(6) \\ 702 & \pm 195^{\mathrm{bc}}(6) \\ 508 & \pm 170^{\mathrm{d}}(4) \\ 3642 & \pm 2446^{\mathrm{cd}}(2)\end{aligned}$

$17 \cdot 5 \pm 1 \cdot 5^{\mathrm{ab}}(43)$

$376 \cdot 5 \pm 164^{\mathrm{a}}$ (9)

$31 \cdot 2 \pm 11 \cdot 0(17)$

$171 \cdot 7 \pm 63 \cdot 9^{\mathrm{b}}(12)$

\begin{tabular}{l}
$\begin{array}{l}\text { Testosterone } \\
(\mathrm{nmol} / \mathrm{l})\end{array}$ \\
\hline \\
$1556 \pm 128^{\mathrm{abc}}(40)$ \\
$176 \pm 97^{\mathrm{a}}(4)$ \\
$298(1)$ \\
$2231 \pm 679(5)$ \\
$1433 \pm 229(4)$ \\
$628 \pm 147^{\mathrm{b}}(5)$ \\
$210 \pm 87^{\mathrm{c}}(4)$ \\
$1196 \pm 905(2)$
\end{tabular}

FSH

(ng/ml)

LH

(ng/ml)

$$
\begin{aligned}
& 298 \pm 26^{\mathrm{ab}}(40) \\
& 710 \pm 360^{\mathrm{a}}(4) \\
& 117(1) \\
& 206 \pm 65(8) \\
& 219 \pm 52(6) \\
& 971 \pm 545^{\mathrm{bcd}}(5) \\
& 177 \pm 78^{\mathrm{d}}(4) \\
& 222 \pm 140^{\mathrm{c}}(2)
\end{aligned}
$$

$$
\begin{aligned}
12 \cdot 8 & \pm 1 \cdot 4^{\mathrm{a}}(43) \\
2 \cdot 5 & \pm 1 \cdot 0^{\mathrm{a}}(9) \\
10 \cdot 6 & \pm 2 \cdot 8(13) \\
11 \cdot 2 & \pm 2 \cdot 6(11)
\end{aligned}
$$

$$
\begin{array}{ll}
5 \cdot 0 \pm 0 \cdot 5^{\mathrm{a}}(43) & 5 \cdot 0 \pm 0 \cdot 5^{\mathrm{ab}}(43) \\
1 \cdot 2 \pm 0 \cdot 3^{\mathrm{a}}(10) & 2 \cdot 4 \pm 0 \cdot 6^{\mathrm{a}}(13) \\
3 \cdot 8 \pm 0 \cdot 8(17) & 3 \cdot 7 \pm 0 \cdot 6(16) \\
3 \cdot 3 \pm 0 \cdot 9(12) & 2 \cdot 4 \pm 0 \cdot 3^{\mathrm{b}}(12)
\end{array}
$$


Table 3 Correlations between hormone concentrations in dogs with Sertoli cell tumours and dogs with Leydig cell tumours. Relationships between $\mathrm{LH}$ or FSH and other hormones are calculated from peripheral values; other relationships are from testicular concentrations. The number of measurements on which the calculation was performed is indicated in parentheses

\begin{tabular}{|c|c|c|c|c|c|}
\hline & LCT & & & & \\
\hline & Inhibin & Oestradiol & Testosterone & FSH & $\mathrm{LH}$ \\
\hline SCT & 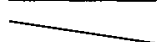 & & & & \\
\hline Oestradiol & $0 \cdot 76(4)$ & & $-0.47(7)$ & $-0.36(12)$ & $-0.36(11)$ \\
\hline Testosterone & $-0.93^{\star}(4)$ & $-0.90^{\star}(4)$ & ב & $-0.22(11)$ & $-0.41(11)$ \\
\hline FSH & $-0.37(9)$ & $-0.57^{\star}(10)$ & $0.08(9)$ & & 0.45 (11) \\
\hline
\end{tabular}

LCT (upper right half), dogs with a Leydig cell tumour; SCT (lower left half), dogs with a Sertoli cell tumour. Asterisks indicate significant correlations.

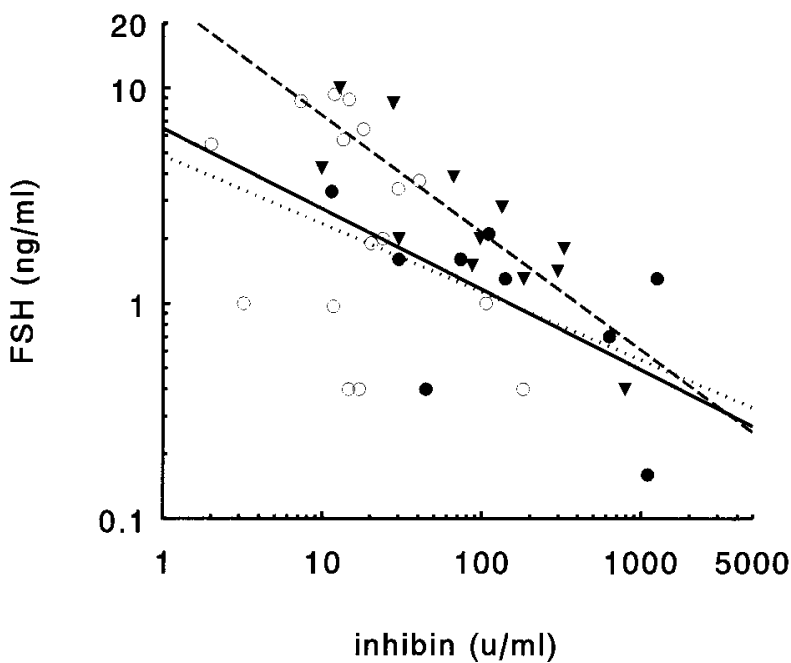

Figure 5 Relationship between inhibin and FSH in peripheral venous blood of dogs with a Sertoli cell tumour $(\bullet$, dotted line), a seminoma $(\bigcirc$, solid line) or a Leydig cell tumour $(\boldsymbol{\nabla}$, dashed line).

were severely depressed (Table 2). The concentration of $\mathrm{LH}$ in peripheral venous blood was depressed $(P=0 \cdot 02)$, whereas that of FSH in peripheral venous blood was comparable to that in normal dogs (Table 2).

In dogs with a Leydig cell tumour, the concentration of testosterone was positively correlated $(P=0.03)$ with the concentration of inhibin in testicular venous blood (Table $3)$. The negative relationships between the concentrations of testosterone, oestradiol and inhibin on the one hand and $\mathrm{LH}$ and $\mathrm{FSH}$ on the other were not significant in dogs with Leydig cell tumours (Table 3), with the exception of the relationship between inhibin and FSH (Fig. 5).

\section{Dogs with a seminoma}

No signs of feminisation were reported in this group $(n=19)$. Testes containing a seminoma produced inhibin, oestradiol, and testosterone in concentrations comparable to those produced by the unaffected contralateral testis and to those in dogs with normal testes (Table 2).

Significant correlations between hormone concentrations in peripheral venous blood were found between LH and FSH $(r=0.59, P=0.02, n=15)$ and between LH and testosterone $(r=0 \cdot 67, P=0 \cdot 01, n=13)$.

\section{All dogs}

There was a correlation between peripheral venous values and testicular venous values of inhibin-like immunoreactivity, oestradiol and testosterone. The correlation coefficients were $0.32,0.80$ and 0.32 respectively, and all were significant $(P<0 \cdot 025 ; n=60,55$ and 52 respectively). Furthermore, the relationship between inhibin and FSH in the total group of dogs was significant $(r=-0 \cdot 43, n=88$, $P<0 \cdot 0005)$.

\section{Discussion}

The concentrations of gonadotrophins, inhibin and testosterone in testicular and peripheral venous blood of healthy dogs did not change with age. Others have reported decreased concentrations of testosterone and LH with increasing age (Bondarenko et al. 1979, Günzel Apel et al. 1990). In our study, oestradiol concentrations in testicular venous blood decreased slightly with age, but this effect was not detected in peripheral venous blood. In men, serum concentrations of oestradiol remain unaltered or gradually increase with advancing age, suggesting an increased production of oestradiol (Meites 1986). The increased production of oestradiol may take place in the testis, but also in adipose tissue where testosterone is converted to oestradiol by the enzyme aromatase. An increase in the activity of peripherally localised aromatase has been described in ageing women (Longcope \& Baker 1993) and this could also be the case in aged dogs. Such an increased peripheral conversion from testosterone to 
oestradiol could explain why peripheral venous concentrations of oestradiol are maintained despite slightly diminished testicular production of oestradiol.

In the present study we used dogs of different breeds weighing from 5 to $60 \mathrm{~kg}$ and found that the weight did not influence concentrations of steroids, gonadotrophins or inhibin-like immunoreactivity in testicular and peripheral venous blood. This is a new finding, as in most published studies only beagle dogs were used (James \& Heywood 1979, Lowseth et al. 1990) or differences in body and thus testes size were ignored (Taha \& Noakes 1982). Our finding is in accordance with those of a study in which no relation was found between the size of the animal and testosterone concentrations in 10 different species (Wichmann et al. 1984).

In dogs with Sertoli cell tumours there was an increase in inhibin-like immunoreactivity in both testicular venous blood and peripheral venous blood. This observation confirms results of an earlier study in which Sertoli cell tumours were found to contain increased concentrations of bioactive inhibin (Grootenhuis et al. 1990). The concentrations of oestradiol in both testicular and peripheral venous blood were significantly greater in dogs with Sertoli cell tumours than in unaffected animals. Tumorous Sertoli cells in the canine testis are generally believed to be the source of oestrogen in dogs with feminisation, but unchanged concentrations of oestradiol in feminised dogs have also been reported, probably because of differences in the methods used for the measurements of oestradiol (Siegel et al. 1967, Comhaire 1974, Morgan 1982, Grootenhuis et al. 1990). Indeed, re-assay of the samples discussed by Grootenhuis et al. (1990) using the method described in this study yielded differences between normal dogs and dogs with feminising Sertoli cell tumours that were similar to those found in the present study (Rijnberk 1996).

In this study we showed specifically that the testis containing a Sertoli cell tumour produces greater concentrations of oestradiol and inhibin-like immunoreactivity, by measuring concentrations in testicular venous blood. Oestradiol can suppress both FSH and LH secretion in males in a number of species (Swerdloff \& Heber 1983), but in male dogs oestradiol mainly regulates LH secretion (Winter et al. 1983). We found this to be reflected by a strong negative correlation between oestradiol and LH. The concentrations of both $\mathrm{LH}$ and FSH were found to be suppressed, probably because of increased inhibin and oestradiol concentrations. This gonadotrophic suppression resulted in significantly lower testosterone concentrations. In accordance with the above, we found a negative correlation between testosterone and inhibin and between testosterone and oestradiol.

Inhibin-like immunoreactivity was increased in dogs with Leydig cell tumours. In the rat and the mouse, Leydig cell tumours have also been shown to contain immunoreactive inhibin (de Winter et al. 1992). Furthermore, significantly increased concentrations of oestradiol were found in testicular venous blood. In two dogs with Leydig cell tumours, the amount of oestrogens secreted was great enough to cause feminisation. It is unclear whether remaining Sertoli cells in the seminiferous tubules secreted this oestradiol or whether the Leydig tumour cells are capable of doing this. The neoplastic cells might produce a factor that stimulates the aromatase activity in the remaining Sertoli cells.

As Leydig cells produce testosterone, testes with Leydig cell tumours might be expected to secrete greater concentrations of this steroid (Chalmers \& Medleau 1990). Instead, we observed decreased concentrations of testosterone in testicular venous blood, probably caused by oestradiol-induced suppression of LH. However, testosterone concentrations in peripheral venous blood from dogs with Leydig cell tumours were not significantly different from those in normal dogs. This may be explained in either of two ways. First, the testicular blood flow in these dogs may have been increased, resulting in a lower testicular venous testosterone concentration, but unchanged testosterone production. Secondly, the observed increase in the oestradiol concentration may lead to a greater concentration of androgen-binding protein and thus decreased clearance of testosterone, causing a relative increase in peripheral testosterone concentrations.

In dogs with Leydig cell tumours the LH concentration in peripheral venous blood was decreased and there was a negative correlation with testosterone, oestradiol, and inhibin. This is in accordance with suppression of the LH response to gonadotropin-releasing hormone by oestrogens, as was implicated in an earlier study (Winter et al. 1983).

As the concentration of FSH was not decreased in these dogs, we believe that the increased immunoreactive inhibin was not bioactive. This suggests that Sertoli cell tumours secrete bioactive dimeric inhibin, resulting in a reduced concentration of FSH, whereas Leydig cell tumours produce loose $\alpha$-subunits that are known to cross-react in the inhibin assay used in this study. This is in agreement with observations in the rat and the mouse, in which immunoreactive inhibin secreted by Leydig cell tumours often was not biologically active (de Winter et al. 1992).

A remarkable finding was the extremely high inhibinlike immunoreactivity found in bilaterally occurring Leydig cell tumours in two dogs that had normal concentrations of oestradiol. One of these dogs had soft testes and increased gonadotrophin concentrations, whereas in the other dog the gonadotrophin concentrations were decreased. This suggests that bilateral Leydig cell tumours may differ in biological behaviour compared with unilateral Leydig cell tumours.

Despite the fact that aromatase activity and thus the ability to synthesise oestrogens has been demonstrated in germinal cells of mice (Nitta et al. 1993), bears (Tsubota 
et al. 1993) and roosters (Kwon et al. 1995), seminomas in dogs are believed not to secrete oestrogen and indeed are known to be hormonally inactive (Nielsen \& Kennedy 1990, Chastain 1993). When signs of feminisation are present, they are probably due to a co-existing tumour that has not been detected (Nielsen \& Kennedy 1990). In support of this hypothesis, we found that testosterone, oestradiol and inhibin concentrations in dogs with seminomas were not significantly different from those in control dogs. The facts that aromatase has been demonstrated mainly in spermatids (Nitta et al. 1993, Tsubota et al. 1993) and that canine seminomas are believed to be of spermatocytic origin (Looijenga et al. 1994) could explain the unaltered oestradiol concentrations found in this group of dogs.

It can be concluded that, in dogs, age does not affect the production of steroids, gonadotrophins or inhibin, with exception of testicular oestradiol, for which a negative correlation with increasing age was found. In Sertoli cell tumours and Leydig cell tumours, the concentrations of steroids, gonadotrophins and inhibin were strongly altered, sometimes leading to feminisation, but there was no demonstrable change in the hormone production by testes with seminomas. Finally, we conclude that feminisation in dogs with a Sertoli cell tumour or a Leydig cell tumour is caused by increased concentrations of oestrogen.

\section{Acknowledgements}

We are grateful to all veterinarians who collected blood, especially the clinicians in the Department of Clinical Sciences of Companion Animals, the clinicians from Dierenkliniek Batau, Dierenkliniek Delft-Centrum and other private clinics. Many thanks to C P M Sprang, $M$ van Wolferen, A Slob and J Wolfswinkel, who also collected many samples, and to M A Timmerman and DM Blankenstein, who performed all hormone measurements. We appreciate the critical reading of this manuscript by Dr B E Belshaw.

\section{References}

Bondarenko LA, Vartapetov BA \& Gladkova AI 1979 Comparative evaluation of secretion of testicular androgens and excretion of their metabolites in young and old dogs. Problemy Endokrinologii 25 78-80.

Bukovsky A, Chen TT, Wimalasena J \& Caudle MR 1993 Cellular localization of luteinizing hormone receptor immunoreactivity in the ovaries of immature, gonadotropin-primed and normal cycling rats. Biology of Reproduction 48 1367-1382.

Chalmers SA \& Medleau L 1990 Identifying and treating sexhormone dermatoses in dogs. Veterinary Medicine 85 1317-1324.

Chastain CB 1993 Feminizing testicular tumour. Compendium on Continuing Education for the Practicing Veterinarian 15 197-201.

Chen H, Hardy MP, Huhtaniemi I \& Zirkin BR 1994 Age-related decreased Leydig cell testosterone production in the brown Norway rat. Journal of Andrology 15 551-557.
Comhaire F 1974 Testosterone and oestradiol in dogs with testicular tumours. Acta Endocrinologica 77 408-416.

Faustin FM, Carani C \& Teerds KJ 1995 Characterization of bilateral androgen-secreting tumours in a patient with Nelson's syndrome and hypogonadotropinemia. In Cellular and Molecular Regulation of Testicular Cells, pp 1-21. Raleigh, NC: Serono Symposia.

Finch CE \& Schneider EL 1985 In The Biology of Aging, pp 478-510. Eds CE Finch \& EL Schneider. New York: Van Nostrand Reinhold Company.

Goldston RT, Mosier JE \& Krawiec DR 1989 In The Veterinary Clinics of North America, pp ix-84. Ed RT Goldston. Philadelphia: WB Saunders Company.

Grootenhuis AJ, van Sluijs FJ, Klaij IA, Steenbergen J, Timmerman MA, Bevers MM, Dieleman SJ \& de Jong FH 1990 Inhibin, gonadotrophins and sex steroids in dogs with Sertoli cell tumours. Journal of Endocrinology 127 235-242.

Günzel Apel AR, Brinckmann HG \& Hoppen HO 1990 Dynamik der LH- und Testosteron-Sekretion bei Beagle-Rüden verschiedener Altersgruppen. Reproduction in Domestic Animals 25 $78-86$.

Hayes HM, Wilson GP, Pendergrass TW \& Cox VS 1985 Canine cryptorchism and subsequent testicular neoplasia: case-control study with epidemiologic update. Teratology 32 51-56.

James RW \& Heywood R 1979 Age-related variations in the testes and prostate of beagle dogs. Toxicology 12 273-279.

Kaiser FE \& Morley JE 1994 Gonadotropins, testosterone, and the aging male. Neurobiology of Aging 15 559-563.

Karpas AE, Bremner WJ, Clifton DK, Steiner RA \& Dorsa DM 1983 Diminished luteinizing hormone pulse frequency and amplitude with aging in the male rat. Endocrinology 112 788-792.

Knol BW, Dieleman SJ, Bevers MM \& van den Brom WE 1993 GnRH in the male dog: dose-response relationships with LH and testosterone. Journal of Reproduction and Fertility 98 159-161.

Kwon S, Hess RA, Bunick D, Nitta H, Janulis L, Osawa Y \& Bahr JM 1995 Rooster testicular germ cells and epididymal sperm contain P450 aromatase. Biology of Reproduction 53 1259-1264.

Longcope C \& Baker S 1993 Androgen and estrogen dynamics: relationships with age, weight, and menopausal status. Journal of Clinical Endocrinology and Metabolism 76 601-604.

Looijenga LH, Olie RA, van der Gaag I, van Sluijs FJ, Matoska J, Ploemzaaijer J, Knepfle C \& Oosterhuis JW 1994 Seminomas of the canine testis - counterpart of spermatocytic seminoma of men? Laboratory Investigation 71 490-496.

Lowseth LA, Gerlach RF, Gillett NA \& Muggenburg BA 1990 Age-related changes in the prostate and testes of the beagle dog. Veterinary Pathology 27 347-353.

Meites J 1986 The neuroendocrinology of hypothalamic aging. Neuroendocrine Perspectives 5 179-189.

Morgan RV 1982 Blood dyscrasias associated with testicular tumors in the dog. Journal of the American Animal Hospital Association 18 970-975.

Mosier JE 1989 Effect of aging on body systems of the dog. Veterinary Clinics of North America 19 1-12.

Neaves WB, Johnson L, Porter JC Jr \& Petty CS 1984 Leydig cell numbers, daily sperm production, and serum gonadotropin levels in aging men. Journal of Clinical Endocrinology and Metabolism $\mathbf{5 9}$ 756-763.

Nielsen SW \& Kennedy PC 1990 Tumors of the genital systems. In Tumors in Domestic Animals, pp 479-517. Ed JE Moulton. Berkeley: University of California Press.

Nitta H, Bunick D, Hess RA, Janulis L, Newton SC, Millette CF, Osawa Y, Shizuta Y, Toda K \& Bahr JM 1993 Germ cells of the mouse testis express P450 aromatase. Endocrinology 132 1396-1401.

Peters MAJ \& van Sluijs FJ 1996 Testicular tumors in dogs: a literature review [in Dutch]. Tijdschrift Diergeneeskunde 121 36-38.

Rijnberk A 1996 Testes. In Clinical Endocrinology of Dogs and Cats, pp 119-130. Ed A Rijnberk. Dordrecht: Kluwer Academic Publishers. 
Robertson DM, Giacometti M, Foulds LM, Lahnstein J, Goss NH, Hearn MT \& De Kretser DM 1989 Isolation of inhibin alphasubunit precursor proteins from bovine follicular fluid. Endocrinology 125 2141-2149.

Sharpe RM 1998 The roles of oestrogen in the male. Trends in Endocrinology and Metabolism 9 371-377.

Siegel ET, Forchielli E, Dorfman RI, Brodey RS \& Prier JE 1967 An estrogen study in the feminized dog with testicular neoplasia. Journal of Endocrinology 80 272-277.

Swerdloff RS \& Heber D 1983 Superactive gonadotropin-releasing hormone agonists. Annual Review of Medicine 34 491-500.

Swerdlow AJ 1993 The epidemiology of testicular cancer. European Urology 23 35-38.

Taha MB \& Noakes DE 1982 The effect of age and season of the year on testicular function in the dog, as determined by histological examination of the seminiferous tubules and the estimation of peripheral plasma testosterone concentrations. Journal of Small Animal Practice 23 351-357.

Teerds KJ, de Boer-Brouwer M, Dorrington JH, Balvers M \& Ivell R 1999 Identification of markers for precursor and Leydig cell differentiation in the adult rat testis following ethane dimethyl sulphonate administration. Biology of Reproduction $\mathbf{6 0}$ 1437-1445.

Theilen GH \& Madewell BR 1987 Tumors of the male reproductive system. In Veterinary Cancer Medicine, pp 591-600. Eds GH Theilen \& BR Madewell. Philadelphia: Lea and Febiger.

Tsubota T, Nitta H, Osawa Y, Mason JI, Kita I, Tiba T \& Bahr JM 1993 Immunolocalization of steroidogenic enzymes, P450 scc, 3
beta-HSD, P450c17, and P450 arom in the Hokkaido brown bear (Ursus arctos yesoensis) testis. General and Comparative Endocrinology $92439-444$.

Verjans HL, Cooke BA, Jong FH, Jong CM \& Molen HJ 1973 Evaluation of a radioimmunoassay for testosterone estimation. Journal of Steroid Biochemistry 4 665-676.

Wang C, Leung A \& Sinha HA 1993 Reproductive aging in the male brown-Norway rat: a model for the human. Endocrinology 133 2773-2781.

Wichmann U, Wichmann G \& Krause W 1984 Serum levels of testosterone precursors, testosterone and estradiol in 10 animal species. Experimental Clinical Endocrinology 83 283-290.

de Winter JP, Timmerman MA, Vanderstichele HMJ, Klaij IA, Grootenhuis AJ, Rommerts FFG \& de Jong FH 1992 Testicular Leydig cells in vitro secrete only inhibin alpha-subunits, whereas Leydig cell tumors can secrete bioactive inhibin. Molecular and Cellular Endocrinology 83 105-115.

Winter M, Falvo RE, Schanbacher BD \& Verholtz S 1983 Regulation of gonadotropin secretion in the male dog. Role of estradiol. Journal of Andrology 4 319-323.

Zirkin BR, Santulli R, Strandberg JD, Wright WW \& Ewing LL 1993 Testicular steroidogenesis in the aging brown Norway rat. Journal of Andrology 14 118-123.

Received 6 September 1999

Revised manuscript received 14 February 2000

Accepted 7 March 2000 